\title{
FISCAL-BUDGETARY POLICY AS A STIMULATION TOOL OF ECONOMIC GROWTH AND OF THE LEVEL OF THE FINANCIAL RESOURCES OF THE STATE
}

\author{
Elena FLORIȘTEANU*, Dragoș FLORIȘTEANU** \\ *“Nicolae Bălcescu" Land Forces Academy, Sibiu, Romania \\ **Holcim, Sibiu, Romania \\ elena_floristeanu@yahoo.co.uk,dragoshflo@ymail.com
}

Motto: "Government's view of the economy could be summed up in a few short phrases: If it moves, tax it. If it keeps moving, regulate it. And if it stops moving, subsidize it." (Ronald Reagan, U.S. President)

\begin{abstract}
The fiscal and budget policies developed over the last few years by policy makers emphasize fiscal relaxation measures in order to stimulate economic growth. Expected by employers and employees alike, they sometimes lead to results opposite to those pursued, especially if they do not take into account the particularities of the economic domains concerned and the social realities of the state. Due to the limited and often insufficient financial resources, it is necessary to stimulate those areas considered as generators of growth, and a good example in this sense is the research, development and innovation. In the context of the difficulties of ensuring an optimal level of public funding, it becomes increasingly obvious that legislative changes of fiscal and budgetary nature and how they can be implemented can be both a basis for the sustainability of public finances and for increasing competitiveness and a disturbing factor in the labor market and progress.
\end{abstract}

Keywords: fiscal-budgetary policy, economic growth, public income, public expenditure, tax revenue

\section{Introduction}

The elaboration of the article was informed by various relevant works dealing with the addressed issues, elaborated by Romanian authors (Croitoru, 2015, Georgescu F (2017), Dumitru and Stanca, 2010, Talpoş and Avam, 2011, Văcărel et al., 1999, Hoanță, 2000, Corduneanu, 1998, Manolescu, 1997, Şaguna, 1996) and from abroad (Hagemann, 2018, Gemmel and al., 2016, Bergh and Henrekson, 2011, Gray and Lane, 2007, Tanzi, 2005, Talvi, 2000) whose opinions have influenced the theory, as well as the results presented in various reports made public by different national and international organizations or institutions with responsibilities in the field (Ministry of Public Finance, National Institute of Statistics, National Bank of Romania, the European Commission, the International Monetary Fund, the World Bank).

The fiscal-budgetary policies applied by each state at a given moment represent the choices of the government/political parties in power regarding the fulfillment of the economic and social objectives set out in the promoted development strategies or 
programs. With the help of the two components of financial policy, namely fiscal and budgetary policy, policy makers implement economic measures aimed at growth, job creation and the promotion of technical and social progress targeting the improvement of education, health services, social protection and culture, and measures specific to addressing the need to strengthen defense, public order and national security.

Given the fact that financial policy is an integral part of a state's economic policy, once the objectives of financial policy have been achieved, higher-level objectives pursued through economic policy are also met. That is why at the heart of all the actions undertaken through fiscal-budgetary policies should be the economic and social development of the country and the provision of public goods and services that the society cannot dispense of and without which it cannot evolve.

Achieving the goals pursued within the expected parameters requires significant financial resources, and the accomplishment at the forecasted level depends on the "talent" and skill of those who issue and apply both the economic and the financial policies of the state. Nevertheless, there are situations in which political parties make electoral offers of public goods and services for whose postelection insurance "force" the objectives proposed by fiscal-budgetary policies and are not consistent with the economic realities of the state. In this regard, TalpoşAnthony Downs noted that the parties in power "formulated policies in order to win the elections, instead of winning elections to formulate policies." [1]. National and international experiences have demonstrated how important it is for those who develop economic and financial-budgetary policies to discard temporary political interests and build policies that go beyond the electoral cycle and address national realities, without neglecting the European and international trends in the field.

\section{Basic Concepts and Theoretical Framework}

The article highlights the way in which a state, through adopted fiscal-budgetary policies can influence the growth and the level of public revenues. The discussion pivots on some approaches regarding the concepts under consideration and their forms of manifestation.

Specialized literature presents many perspectives on fiscal and budgetary policy and, due to the interdependence between them, they are often discussed together. Differences occur when defining and especially when referring to composition or application. There are situations in which fiscal policy is approached as a stand-alone component of the state's financial policy regarding the revenue aspect (Corduneanu, 1998) and others that show that fiscal policy has revenue at the core of its objectives, but in view of the fact that it represents the basis for financing budget expenditures, it is seen as a component of budgetary policy (Manolescu, 1997) or as containing both the revenue and the expenditures (Samuelson, 1967). Some of the mentioned definitions will be further explained.

The revenue-focused fiscal policy "establishes the sources, methods of taxing and generating budget revenues". Budgetary policy, which is dealt with separately from fiscal policy and is oriented towards the expenditure aspects, is an "expression of the sizing and ranking of budget expenditures through specific actions and instruments" [2]. The first group of approaches also falls within the definition according to which fiscal policy refers to "all fiscal decisions taken by the political decision maker so as to provide financial resources to finance public needs and to achieve economic and social ends" [3]. In the second group of theoreticians, Gheorghe Manolescu divides the fiscal policy into three components, such as: a. tax policy referring to the revenues obtained from taxes and duties; b. allocation policy (or narrow budget policy) in which budget 
expenditure items are tracked; c. the budget balance policy, which refers to the financial resources borrowed for financing the deficit and the capitalization of the budgetary excess. [4] It results that fiscal policy has a narrower sphere than fiscal policy, which uses both taxes and duties, as well as spending and budget balance as levers to achieve its own objectives.

A corollary of the above is encapsulated in the definitions given in the Economy Dictionary, according to which fiscal policy "designates the state's concepts, measures and actions in the formation of budget revenues and the financing of budgetary expenditures, types of taxes, their perception and use as a tool to stimulate economic growth", while budget policy represents "the state's concept and actions regarding budget revenues and expenditures, ways and means of mobilizing revenue, types and sizes of spending that can directly intervene against shocks and instability, for economic revival" [5]. Used as an instrument of intervention in the economy, fiscal policy is represented by the "changes in government spending and taxes that are designed to achieve macroeconomic policy objectives.'[6]

The effects of financial policies are felt both over short and long periods. That is why governments are not just using financial policy as a means of obtaining the financial resources needed to make budget expenditures, but they transform it into an instrument able to influence the economic and social environment, intervening to "promote essential and sustainable growth and to reduce poverty." [7] Therefore, fiscal instruments contribute to "covering public expenditures and allow for a certain equalization of social conditions or provoke, through incitement, economic development." [8]

Regardless of the approach taken to discuss economic theories developed over time that refer to economic growth, it is agreed that both fiscal and budgetary policy influence economic growth, even if in different ways and at different levels.

The discussion of the concept of economic growth makes it necessary to develop on its significance. In brief, the economic literature defines economic growth as the addition of goods and services produced by a country's economy over a certain period of time.

Gross domestic product (GDP), expressed in nominal or real values is used for the measurement of economic growth of a state. The level of growth can be reflected by the absolute or relative (percentage) of the values registered over the compared periods of time (for relevance, data recorded over a longer period of time is used.) To reflect the differences between the states regarding the living standard of the inhabitants, the GDP per capita is used, expressed in PPS (Purchasing Power Standard).

\section{Fiscal and Budgetary Policy Coordinates \\ 3.1. Aspects Regarding the Correlation between Fiscal-Budgetary Policy and the Phases of the Economic Cycle}

Fiscal-budgetary policies are contained in the fiscal-budget normative acts adopted by the governments of each state. The measures initiated and the objectives they target make the difference between states that seek both sustainable economic growth and consolidation of public finances, and those countries that have the objective of obtaining budgetary revenues (immediately or as soon as possible) to cover the expenses they have promised to the electorate. Starting from the behaviors encountered by economic and financial decision-makers, the possibilities of building fiscal-budgetary policies are often discussed, so as to avoid confronting states with precarious fiscal positions or disturbances of the economic environment that affect their objectives of growth and competitiveness. 
Drawing from economic research, we can state that the central idea is that the development of the fiscal-budgetary policy needs to be elaborated according to the phase of the economic cycle. It is therefore important to establish the phases of economic activity: expansion, stagnation or declining.

Depending on the phase of the economy, there are several approaches, as follows: Keynesian standard models (supported by many economists) show that fiscal policy has to be counter-cyclical: expansive policy in times of recession and restrictive in times of expansion. For example, in bad economic times, governments should increase government spending and cut taxes, and in times of expansion they should do the opposite [9]. Neoclassical models, illustrated by Barro (1979), have another approach, according to which the fiscal policy should remain essentially neutral in relation to the economic cycle. Fighting the neutrality of fiscal policies, Vito Tanzi argues that such a "faithfully and fairly-applied policy ... would produce a zero-fiscal deficit over the cycle, if the debt accumulated during a recession were redeemed during the growth". The author considers that since these are exceptions, it means that the application of more restrictive tax rules is justified [10]. The recommendations made by Florin Georgescu follow the same line, and show that the fiscal-budgetary policy, conceived according to the economic cycle phase "... needs to be anti-cyclical or at least neutral in the moment of impetus and stimulating when the economy is in the recession phase" [11].

A particularity identified by some researchers in the field (Gavin and Perotti (1997), Talvi and Végh (2005), is that developing countries are inclined towards pro-cyclical fiscal-budgetary policies, while developed countries prefer acyclicality or counter-cyclicality [12].

An important role in making sound fiscal policy decisions is the strengthening of the institutional framework which, as shown in other studies, has enabled developing countries to escape the pro-cyclical trap [13]. Procyclicality, which is often presented in view of the negative effects that accompany it, defines "fiscal-budgetary behavior of governments that, sometimes motivated by short-term political objectives, tend to spend more when the economy is rising instead of generating surpluses to prevent a further decline, and spend less when the economy is affected by a slowdown or recession, thus aggravating the situation." [14].

The results of fiscal-budgetary policies undertaken by governments are reflected in the response given by the economy, considering that while anti-cyclical fiscal policy stimulates long-term economic growth, pro-cyclical fiscal policy inhibits it (Aghion and Marinescu, 2007; Aghion, Hemous, and Kharroubi, 2009), especially in countries with low financial intermediation [15].

\subsection{Implications of the Fiscal-Budgetary Policy Structure}

Fiscal policy fulfills its role as a macroeconomic stabilizer with the help of both its cyclicality and of the stabilizers on which it relies (automated or discretionary), the channels through which it operates, the aggregate demand or supply. For each state, fiscal stabilizers help save money to adjust to asymmetric shocks. Although the built-in (automatic) stabilizers offer the advantage of steadying the business cycle automatically, through "self-regulation", due to the levying of taxes and duties as provided for in the Fiscal Code, and by the compliance with the financial and budgetary rules, these stabilizers are not sufficiently exploited by decision-makers of fiscal and budgetary policies.

Most often, for stimulating economic activity and raising revenues, states are making easy use of discretionary fiscal policy instruments that involve political decisions to change government taxes and spending. However, discretionary fiscal policy calls for increased attention because the effectiveness of the taken measures is 
influenced both by the structure of the expenditure and by the revenue generated by the manipulation of the tax base and the rate of taxation. Numerous studies in the field demonstrate the impact of multipliers used in the allocation of resources between the public and private sectors and implicitly on consumption, saving or investment behavior. Relevant to the above is the opinion of Dan Şaguna, who posits that "the biggest and most prudent science of taxation promoted by the government is to know how to secure the state's and the society's income, without it being a burden or a serious harm to the private interests and heritage of the physical and legal individuals." [16]

A macroeconomic model developed in OECD countries, notes that short-term multipliers stemming from government spending growth generally outweigh the results of revenue measures. In what regards the multiplier factors consisting of income measures, it is argued that the reduction in personal income tax tends to have a slightly greater effect than other forms of tax reduction [17]. Furthermore, Åsa Johansson argues that the structure and efficiency of government spending can support long-term growth when spending is geared towards increasing investment in physical and human capital, research and development or infrastructure, especially when market failures lead to an insufficient investment by the private sector [18].

Studies by the IMF illustrate the effects of labor tax income, as compared to those determined by capital income taxation. Thus, while the increase by 1 percentage point of the capital income tax rate decreases the increase by 0.02 percentage points, the increase by 1 percentage point of the rate of the labor income tax decreases the increase by 0.22 percentage points. This also highlights that public investment, particularly in infrastructure, can increase production capacity and growth potential of the economy. The largest profits from public investment are recorded in developing economies with large infrastructure gaps. Among the capital expenditure categories, the most notable are the results from transportation and communication costs, which have the highest probability of accelerating the subsequent growth (20\%) [19].

In conclusion, the hypotheses suggesting that some distorting taxes hinder economic growth more than others appear to be sustainable. As a result, corporate taxes and personal income taxes are considered more distortive than consumer or property taxes.

\section{Aspects Regarding Romania's Fiscal- Budgetary Policy}

As previously shown, the efficiency of a fiscal-budgetary policy of a state is dependent on the fiscal-budgetary measures provided by the internal normative framework (in the case of Romania, a EU Member State, and taking into account the concluded European agreements), but also by the mix of implemented fiscal-budgetary instruments. Specialty literature highlights that efficient and fair tax systems are essential for economic growth, poverty reduction, good governance and state consolidation. They tend to lead to higher and more stable incomes, more sustainable investment and increased competitiveness of the economies [20].

By their application and integration with other economic and social policies, these instruments can substantially contribute to enhancing economic performance, increasing social welfare, reducing social disparities and social exclusion. Budgetary revenues are essentially important in covering public expenditure. Also, the funds attracted from the European Union are a crucial part of financing public investment. Economic theories demonstrate the importance of the level and structure of spending and public revenues to achieve growth, employment and social protection objectives for employees.

In recent years, the Romanian tax legislation has undergone numerous 
changes that seriously impacted the labor market, the economic environment, economic growth and the quality of public finances (its components), respectively the level of budget expenditures and revenues. With the help of the data below, it is possible to observe how fiscal policy measures, mainly fiscal relaxation measures, were reflected in the state budget revenues. The analysis will look at both the level of income and at the structure, whose importance has been previously discussed. Particular attention will be paid to tax revenues, which are the main sources of budget revenue coverage.

The study of the normative acts and the analysis of the macroeconomic indicators show that the budgetary receipts were influenced by the economic evolutions as well as by the adopted fiscal policy decisions, such as: the increase of the minimum wage, from ROL 1900 in 2018 to ROL 2080 starting January $1^{\text {st }}, 2019$; reducing the standard VAT rate from $24 \%$ to $19 \%$ and applying a reduced rate of $9 \%$ or $5 \%$ for various deliveries of goods and services; increasing salaries for some categories of employees in the budgetary sector; increasing the retirement point; raising the non-taxable monthly ceiling on pension revenues from ROL 1000 to ROL 2000 and the exemption of pensioners from the payment of social health insurance contributions, as well as the modification of the amount of the excise duties.
According to the forecasts regarding the structure of the budgetary revenues, in 2019 the highest shares of their total will be represented social insurance contributions $34.3 \%$, compared to $27.4 \%$ in 2016 , before the change in the level and the structure of the insurance contributions due by employees and employers. The next place is occupied by the VAT collection - $20.4 \%$. Revenue from excise duties remains low, falling to $9.1 \%$ of the total in 2019 , compared to $12 \%$ in 2016 , before the Fiscal Code was amended.

Furthermore, there is an anticipation of lower wage tax revenue levels $-6.9 \%$ from the total, with the tax rate cut from $16 \%$, as it was in 2017 , to $10 \%$ as of January $1^{\text {st }}$, 2018. The increase of personal deductions from ROL 300 to ROL 510 for those who earn a gross salary of less than ROL 3,600 (increase of $60 \%$ ) is not to be overlooked, especially since it influences the level of income from the salary tax. I also mention that the deduction is reflected in a lower tax burden (tax exemption), which determines the salary level received by the employee. In the same year 2019, the earnings from the profit tax will be $5.0 \%$, a small volume compared to the year 2016 by $1.6 \%$, amid the decrease in the receipts from the economic agents. Amounts drawn from the EU remain at low levels $-9.5 \%$ of the total (Table 1).

Table 1 Structure of budgetary income

\begin{tabular}{|c|c|c|c|c|c|c|c|c|}
\hline Years & $\begin{array}{c}\text { Salary } \\
\text { and } \\
\text { income } \\
\text { tax }\end{array}$ & $\begin{array}{c}\text { Social } \\
\text { insurance } \\
\text { contributions }\end{array}$ & $\begin{array}{c}\text { Income } \\
\text { tax }\end{array}$ & VAT & $\begin{array}{c}\text { Excise } \\
\text { tax }\end{array}$ & $\begin{array}{c}\text { Non- } \\
\text { fiscal } \\
\text { income }\end{array}$ & $\begin{array}{c}\text { EU } \\
\text { contributions } \\
\text { and } \\
\text { donations }\end{array}$ & $\begin{array}{c}\text { Other } \\
\text { income }\end{array}$ \\
\hline 2016 & $12.4 \%$ & $27.4 \%$ & $6.9 \%$ & $23.1 \%$ & $12 \%$ & $8.1 \%$ & $3.1 \%$ & $7.1 \%$ \\
\hline 2017 & $12.0 \%$ & $28.5 \%$ & $5.8 \%$ & $21.3 \%$ & $10.6 \%$ & $8.7 \%$ & $6.8 \%$ & $6.4 \%$ \\
\hline 2018 & $7.7 \%$ & $33.2 \%$ & $5.3 \%$ & $20.2 \%$ & $9.7 \%$ & $9.2 \%$ & $9.2 \%$ & $5.6 \%$ \\
\hline 2019 & $6.9 \%$ & $34.3 \%$ & $5.0 \%$ & $20.4 \%$ & $9.1 \%$ & $8.3 \%$ & $9.5 \%$ & $6.4 \%$ \\
\hline
\end{tabular}

Romanian Government, Fiscal-budgetary strategy for 2019 - 2021, March, 2019

The data outlined highlights a pro-cyclical (expansionist) fiscal-budgetary policy, which, according to forecasts, will continue in the context of anticipating a sustained
GDP growth, thus contributing to a significant acceleration in private consumption. Demand is fueled by strong wage growth, especially in the public sector 
(health and education), but also by the minimum wage, resulting in very substantial increases in unit labor costs. The data provided in the Macroeconomic Situation Report for 2019 and its projection for 2020-2022, elaborated by the Ministry of Public Finance, reveal that in the medium term the budget revenues will increase in nominal terms from RON 341.5 billion as forecast for 2019, to RON 354.8 billion in 2020 and ROL 417.8 billion in 2022 respectively. It is noted that although the nominal values indicate an increase in income levels on the reference horizon, by ROL 76.3 billion in 2022 versus 2019, the percentage value of budgetary revenue in gross domestic product is decreasing, from
$33.40 \%$ as estimated for 2019 to $33.1 \%$ in 2022 , representing a reduction of $0.3 \%$.

In 2019, the structure of budget revenues as a share of GDP reflects an upward trend in social security contributions, reaching 11.47, the anticipated evolution being determined by the projected increase in average earnings and the number of employees. Income tax revenues are projected to fall to $2.3 \%$ of GDP in 2019, being influenced by the negative impact generated by the exemption granted to employees in the construction sector in accordance with GEO No.114/2018. A higher revenue level is expected to be charged on VAT - $6.81 \%$ respectively (Figure 1).

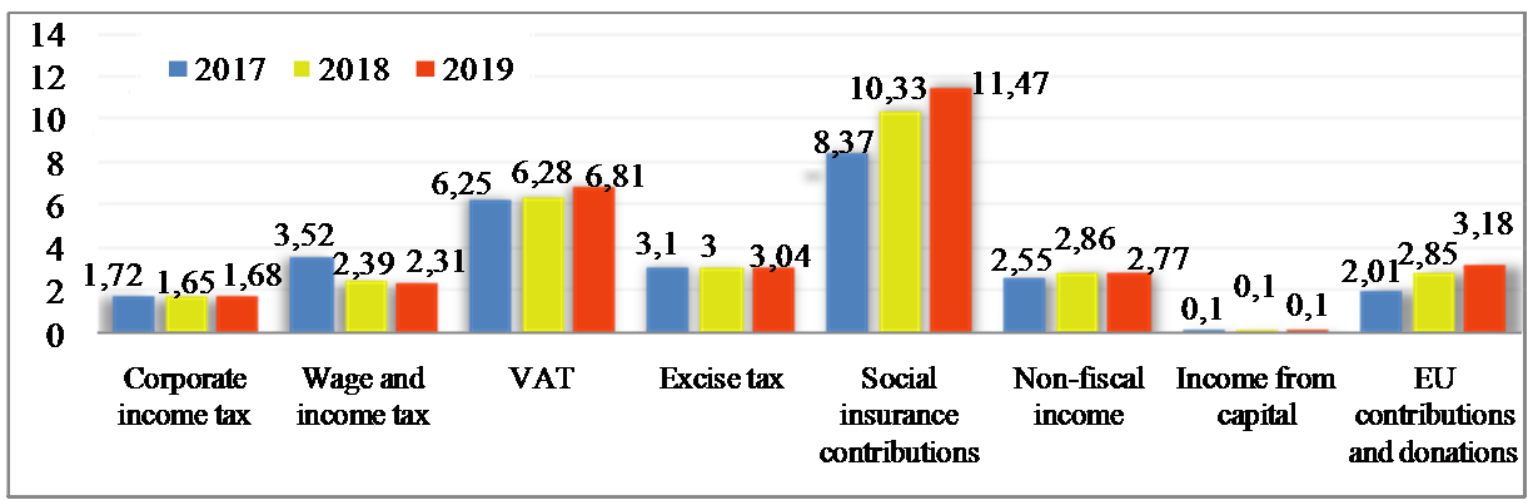

Figure 1: The evolution of Romania GDP budgetary income in 2017 - 2019

Relevant to the low level of income tax are the assessments made in the International Monetary Fund Study in 2014, which confirm that personal income taxes contribute significantly to reducing inequalities in several economies - in fact, in most economies, the redistribution made through income tax is even higher than in the case of means-tested transfers. In turn, social security and other transfers are far less redistributive when viewed from the perspective of the living income [21].

The same trajectory is also followed by other income, as their share in the GDP remains low, as compared to those registered in other EU Member States. I observe that the total weight of taxes, i.e. the sum of taxes and net social contributions as a percentage of the GDP, was $40.2 \%$ in 2017 at the level of the European Union, an increase by $39.9 \%$ since 2016. It is important to show that in Romania, the domestic demand will also represent the engine of economic growth in the next period. According to some statistics for the period 2020-2022, it is estimated that the Romanian economy will register sustained growth with an average annual rate of $5.2 \%$. Although there is no total support for the assessment that differences in overall levels of taxation actually reflect differences in social preferences for public goods, it is important to understand that evolution implies good quality goods and services, which come at a high cost. 


\section{Conclusions}

The low levels of social taxes and spending limit the redistributive impact of fiscalbudgetary policy. Increasing the level of budget revenues is essential for the state to be able to meet its obligations to provide quality goods and services to its own citizens who contribute through economic and social skills to economic growth. Fiscal policy, viewed solely through the prism of the pressure on the income of individuals and legal entities contributing to the budget, through taxes and fees paid, is often brought into question with criticism. The positive effects of revenue redistribution on the sectors leading to progress towards sustainable, quality investments, can lead to increased tax compliance. At the same time, it is necessary to act in order to improve the collection of taxes and duties, to diversify the actions that identify the offenses associated with tax evasion and the money laundering resulting from it, and to increase the transparency and efficiency of allocations.

\section{References}

[1] Anthony Downs, An Economic Theory of Democracy, Editura Harper \& Row, New York, 1957, p. 28.

[2] Văcărel Iulian (coord.), Finanțe publice, Didactică și Pedagogică Publishing House, 1999, p.708.

[3] Corduneanu Carmen, Sistemul fiscal în știința finanțelor, CODECS Publishing House, București, 1998, p. 379.

[4] Manolescu Gheorghe (coord.), Politici economice, concepte, instrumente, experiențe, Economică Publishing House, București, 1997, p. 265.

[5] Angelescu Coralia, Ciucur Dumitru et.al. (Colectiv autori), Dicționar de economie, Economică Publishing House, București, 2001, pp. 336 -.338.

[6] Joseph E. Stiglitz, Carl E.Walsh, Economics, Fourth Edition, W. W. Norton \& Company, New York, 2010, p. 729.

[7] Mark Horton, Asmaa El-Ganainy, Back to Basics: What Is Fiscal Policy?, Finance and Development, June 2009, IMF, p. 52 http:// www.imf.org/ external/ pubs/ ft/ fandd/ 2009/ 06/ pdf/ basics.pdf.

[8] Şaguna Drosu Dan, Drept financiar şi fiscal, Oscar Print Publishing House, Bucureşti, 1997, p.7.

[9] Ernesto Talvi, Carlos A. Végh, Tax Base Variability and Procyclical Fiscal Policy, 1998, p.1.

[10] Vito Tanzi, Fiscal Policy and Fiscal Rules in the European Union, Studies \& Analyses No. 301, Warsaw, June, 2005, p. 9.

[11] Florin Georgescu, Conținutul și calitatea politicii fiscale - în pas cu evoluția și obiectivele societății românești, 2017, www.opiniibnr.ro.

[12] Gavin and Perotti (1997), Talvi and Végh (2005) quoted in Dumitru, I., Stanca, R., Fiscal discipline and economic growth - the case of Romania, Selected Papers of the Scientific Romanian Diaspora, Conference, September 2010, Bucharest, Economica Publishing House, 2011.

[13] César Calderon, Punam Chuhan Pole, Rafael M. López Monti, Cyclicality of Fiscal Policy in Sub-Saharan Africa: Magnitude and Evolution, October 27, 2016, p. 3, https://openknowledge.worldbank.org/bitstream/handle/10986/27606/WPS8108.pdf?seq uence $=1 \&$ isAllowed $=\mathrm{y}$.

[14] European Commission, Semestrul european - Fișă tematică, Guvernanța fiscal-bugetară națională, p. 3. 
[15] Ionut Dumitru, Aspecte privind relația politica fiscal-bugetară - creștere economică, Conferința anuală 2018, România după 10 ani, a Asociația Analiștilor Financiar-Bancari din România, 14 noiembrie 2018.

[16] Șaguna Dan Grosu, Procedura fiscală, București: Oscar Print Publishing House, 1996, p. 50.

[17] International Labour Organization, A review of global fiscal stimulus, EC-IILS Joint Discussion Paper series No. 5, p.14.

[18] Åsa Johansson, Public finance, economic growth and inequality: A survey of the evidence, OECD, 2016, Economics Department Working Paper, No. 1346, p. 5.

[19] International Monetary Fund, Washington, D.C., Fiscal Policy and Long-Term Growth, June 2015, p. 21.

[20] Tax and Development, Cooperating with Developing Countries on Promoting Good Governance in Tax Matters, Communication From The Commission to the European Parliament, The Council and the European Economic and Social Committee, Brussels, $\operatorname{COM}(2010)$ 163, p. 4.

[21] Fiscal Policy and Income Inequality, IMF Policy Paper, International Monetary Fund, January 23, 2014, p.15. 